\title{
The instrumental time of memory: local politics and urban aesthetics in a tourism context
}

2

Received 23 May 2018 Revised 23 September 2018 Accepted 15 October 2018

\author{
Antonio-Miguel Nogués-Pedregal \\ Ciencias Sociales y Humanas, Universitas Miguel Hernández, \\ Elche, Spain
}

\begin{abstract}
Purpose - This paper aims to show that tourism is one of the most perfect creations of the capitalist mode of production insofar as not only does it consume places and territories and perpetuate dependency relations, but in the expressive dimension, it also produces feelings and meanings and generates a new relationship of the past with the present and future (chronotope).

Design/methodology/approach - The study was carried out using a socio-anthropological approach with participant observation over several decades.

Findings - The modes of time are described and how the tourism chronotope shapes the historic centre of a consolidated tourist destination. The case study, analysed with the model of the "conversion of place through the mediation of tourism space", illustrates the prevalence of instrumental and commercial values over one's own aesthetic-expressive values in tourism contexts. This fact encourages the emergence of local political projects and the incorporation of uniformities outside the local place. These processes end up uprooting the anchors from collective memory. The definition of territories according to visitors' imaginaries and expectations encourages the abusive occupation of public space and the adoption of new aesthetic attributes of urban space.
\end{abstract}

Research limitations/implications - Because of the chosen research approach and methodologies, the research results may lack generalisability. Therefore, researchers are encouraged to test both the model and the propositions further.

Originality/value - This study approaches the relationship of the idea Tourism with the idea Development based on the anchors of memory.

Keywords Power, Urban planning, Local politics, Development, Cultural identity

Paper type Research paper

\section{Introduction}

A critic told me a story, which masterfully describes change due to tourism. A white and beautiful town far from the modern city had a square with a beautiful fountain. One day two foreigners arrived and were captivated by the fountain. They sat down on a bench in the square and spent the entire afternoon there looking at it. The two tourists left and told their friends about the beauty of the fountain. Two days later, five people came to the town to see the marvel and were also captivated; a few days later, a bus arrived. From that moment on, waves of tourists arrived

(C) Antonio-Miguel Nogués-Pedregal. Published in Journal of Tourism Analysis: Revista de Análisis Turístico. Published by Emerald Publishing Limited. This article is published under the Creative Commons Attribution (CC BY 4.0) licence. Anyone may reproduce, distribute, translate and create derivative works of this article (for both commercial and non-commercial purposes), subject to full attribution to the original publication and authors. The full terms of this licence may be seen at http:// creativecommons.org/licences/by/4.0/legalcode
Journal of Tourism Analysis: Revista de Análisis Turístico Vol. 26 No. 1, 2019

pp. 2-24

Emerald Publishing Limited 2254-0644

DOI 10.1108/JTA-05-2018-0014 
every day to see the square and fountain. Soon, as if by magic, a stand appeared that sold CocaCola; soon afterwards, a hamburger restaurant. Tourists crowded around the guide, who told them a tale in front of the fountain that nobody in the town had heard of. More buses. More cars. In the square there was no longer room for so many cars and buses to be spread out. Then, the mayor had a wonderful idea: get rid of the fountain and create a parking area for cars in its place (Jurdao Arrones, 1992, p. 287).

Tourism is another name for Power. It not only consumes territories but also, as the story of the fountain shows, produces meanings and creates senses; it destroys some or, simply obliterates others. With the new Spanish economic policy implemented in 1959, the relationship between the notion Tourism and the idea Development became even stronger (Vallejo Pousada, 2013). The ideological reduction of the latter to the urban development and construction of seaside resorts was a consequence that deserves to be studied in greater depth. In any event, in Spain

[...] the mid-1960s witnessed the zenith of lawlessness. Construction almost always began before government authorities were notified. However poorly designed, a completed development was an economic asset, leaving authorities little choice but to approve it retroactively (Pack, 2006, p. 173).

The property development saturation that resulted from those practices should not however make us forget about the need to address other basic issues for scientific understanding of social and cultural dynamics in tourism contexts.

As the increasing scientific literature shows, the idea Development in the form of tourism Tourism Development - conditions the political agenda of public institutions and governs the daily management of a significant part of the economic reality of territories where the tourist industry is present. Indeed:

[...] the UNWTO Statistics and Tourism Satellite Account Programme is committed to developing tourism measurement for furthering knowledge of the sector, monitoring progress, evaluating impact, promoting results-focused management, and highlighting strategic issues for policy objectives[1].

Accordingly, the World Travel and Tourism Council quantifies the economic and employment impact and represents 10.4 per cent of to the World Gross Domestic Product and 313 million jobs, or 9.9 per cent of total employment in 2017[2]. Along with this, the social and cultural consequences of the customary unbridled tourism development are also very well studied (Mason, 2003; Wall and Mathieson, 2006).

Complementing this perspective of the identification of Tourism and Development, which normally focuses on the economic revenues of the former over the latter, and on the ideological framework of Bretton Woods and the Washington Consensus, in this article we describe the particular relationship between the three modes of time (past, present and future), and how this relationship is visible in the historic centre of a consolidated tourist destination: El Puerto de Santa María, in the Bay of Cádiz, in Spain.

To understand this approach, it is important to highlight that the idea Development always refers to the possibilities found within the present in so far as it is projected onto the future and, not as paradoxically as it may seem, this projection always seeks its legitimacy in the past. Indeed, there are several studies (Hernández-Ramírez, 2015) showing that in tourism contexts, the emergence of the idea Tourism Development as a more or less collectively desired thing, produces a new relationship with the past that, firstly, materialises in the production of heritage as a meta-cultural product and, afterwards, in decontextualised and instrumental management of heritage (García García, 1998). A type of tourism management that reveals an approach to memory not as a receptacle of collective identity rooted in the past, but rather as an instrument at the service of the idea
Local politics and urban aesthetics 
Development, its present order of "words and things" and its projection onto the future. In some recent work, we have maintained that this process produces a new chronotope that smashes the collective conscience because it fractures the expressive-symbolic continuity that links the past, present and future (Nogués-Pedregal, 2012b; Nogués-Pedregal et al., 2017). This dissolution of the expressive-symbolic dimension on instrumental rationality results in what Max Weber quite rightly called "disenchantment of the world" (Die Entzauberung der Welt).

From this perspective, in this article, I further examine the conceptualisation of time and more specifically the processes of signification; that is to say, the way in which social groups make sense of daily life through tourism space and, very especially, the urban environment in which they express themselves as a group.

I believe that traditional architecture manifests the cultural development of social groups in a specific territory, and urban planning is the canvas on which these groups, including pressure groups, have written and currently write their cultural continuity. Thus, to explain this significative mediation of tourism space, I have focused on the historic-artistic district of El Puerto de Santa María as a paradigmatic example of the process via which tourist activities, their dynamics and aesthetic principles are incorporated as its own in accordance with a logic that fractures continuity in the production of social and cultural meanings. When this continuity is fractured - and this need not always be the case - the consequences are the already well-known and too marked negative effects of tourism.

To understand the processes of signification, it is essential to address the political and ideological context in in which they take place. This is especially important in the case of the Tourism-Development pairing in Spain because there is an abundance of cases revealing the close link between unsustainable tourism practices and the lack of strategic approaches for local development. These links are shown in all their splendour in areas where there is strong correlation between dependency of the services sector, political instability marked by turncoats, cronyism and fragile pacts between political parties.

The structure of the article is straightforward. First, I offer some historic notes about the origin and evolution of tourist activities in El Puerto; second, the article addresses the socioeconomic context with a special emphasis on the tertiary sector and the tourist industry. Finally, through some illustrations, it is shown how the emergence of populist-style political projects, under the auspices of tourism development, have used tourism as a means of justification and altered the relationship between social groups and the city. This fracture of meaning is especially shown in the adoption of aesthetic criteria that are targeted at the tourism imaginaries of visitors and which produce new urban attributes (Romero Martínez et al., 2015).

With regard to the series of symbolic and technical mechanisms that facilitate the transport, accommodation and entertainment of certain social groups who are detached from their ordinary lives, and the processes that they cause, and that, to summarise, are named as tourism, is the absolute reality that determines the emergence of a distinctive type of local politics. It conditions the designs of cultural activities, changes the calendar of festivities, and above all, as it was sold as a miracle, it exploits the land in suicidal way. Consequently, it also speculates with urban planning and rules out any prospect for development. This would eventually classify the territory in accordance with the cultural sense of its inhabitants; and not, as it is usually done, according to the sense of the use and enjoyment of visitors dictated by the logic of the tourist industry. In inland areas, the series of practices that we call tourism, harnessed with the same promises of the capitalist mode of development of the past, although wrapped in the bucolic images of the adjective rural, imports the models or urban operations from the coastline in their dual instrumental and 
aesthetic dimensions. Besides, it is one of the ideological manifestations that have the greatest impact on the attainment of new meanings. This text should be read from this perspective.

\section{The context: tourism, urban planning and local parties}

Political corruption is present throughout the world and, though it is difficult to offer conclusive explanations about its etiology, clear scientific evidence shows that highly developed countries, long-established liberal democracies, with a free and widely read press, a high share of women in government, and a history of openness to trade, are perceived by business people and their citizens as less corrupt (Treisman, 2007). This global presence of corruption has led to quite a lot of study on the effects of corruption on tourism development demand and/or competitiveness (Das and Dirienzo, 2010; Saha and Yap, 2015). Moreover, news stories in the daily world press point to an intriguing regularity with which cases of political corruption and favouritism in public procurements are broadly acknowledged in tourism contexts. In spite of this, scientific research does not question the causal relationship between both phenomena and thus does not further examine its nature. To the best of my knowledge, the sole study that analyses this relationship in depth clearly concludes that "tourism by itself as an economic activity is a relevant (and positive) factor for explaining the likelihood of local corruption" (Jiménez et al., 2017, p. 520).

In a sense, the "tourism - urban planning - local political corruption" triad should not be surprising, as the model of global tourist development requires large investments in infrastructures that enable, first and foremost, accessibility to the territory (roads, airports and ports) that ensure, as much as possible, a satisfactory stay for visitors (hotels, apartments, restaurants, attractions, etc.) and these activities provide rich profits for the developers. In fact, a large number of studies show that tourism, because of the nature of its economic activity, has boosted urban development and city planning ever since its beginnings (Hanningan, 1995; Stock and Lucas, 2012). In addition, it still does everywhere. Indeed, there are strong strategic alliances between global constructors and tourism entrepreneurs at both global and local level to mutually increase their revenues: Brazil (Aledo Tur et al., 2013), Portugal (Figueira Martins, 2011), India (Palamalai and Kalaivani, 2016), China (Luo et al., 2015), Greece (Triantafyllopoulos, 2017), the USA (Gladstone, 1998) or Southeast Asia (Brahmasrene and Lee, 2017). It is important to point out here that, although it is a product of urban planning development, in some way linked to urban tourism (Hiernaux and González, 2014), urban gentrification has very different consequences (Gravari-Barbas and Guinand, 2017) to those caused by so-called residential tourism.

Some authors believe, quite justifiably, that we need to abandon the term "residential tourism" used to describe and explain the spread of resorts in tourist areas: the dynamics of the tourist industry are different, if not opposed, to those of simple property speculation (Huete Nieves et al., 2008; Mantecón, 2017). In addition, the extensive use of this label by stakeholders is legitimising practices of unbridled exploitation in the territory. Deconstructing the notion Residential Tourism is certainly a first step that we need to further examine. However, it is also important not to be careless with theory by considering that dynamics exist independently of the practices that give them their meaning. Hence, instead of describing and confronting what is being done in the name of Development, scholars should consider the process through which tourism development ends up being what is done by those who say they carry out "tourist development". From this theoretical position, it is crucial to address the distribution of local power, in that as Foucault states, it is power that has the option of imposing its definition of reality. In other words, because a
Local politics and urban aesthetics 
certain social group ends up imposing its definition of reality through the force of deeds, it has power.

The foundation of the "tourism - urban planning - local political corruption" triad is found in the very nature of state organisation. Since its emergence as an historic means of socio-political organisation, effective management of the territory is one of the basic characteristics of the state and, by extension, of the body of administrative agents that comprise it at its different levels. Hence, why any action aimed at modifying the territory needs to have the mandatory permits issued by the competent authorities. In addition, construction activity always changes the territory. In most countries, administrative procedures relating to construction can be slowed down or sped up according to the actions of the person in charge of the procedure and with whom, the checks are perhaps less strict.

In the case of Spain, for instance, an increasing number of studies highlight the strong correlation between local political corruption and urban planning which is also found more often in tourist areas (Baron-Yelles, 2010; Benito et al., 2015; Jeréz Darias et al., 2012). This is especially the case when, because of the level of decentralisation of the Spanish public administration, the local administration plays a crucial role in development (Díaz Fernández, 2009).

There is also an interesting political dimension which points to the fact that, although none of the most important political parties in Spain have been untainted by corruption scandals, the evidence shows that a large majority of these cases of corruption linked to urban planning have taken place within local parties in tourism municipalities (Jiménez et al., 2017). The emergence of these local parties can be placed within the framework of the general process of the new democratic localism that emerged in Europe (Navarro Yáñez, 1997) or because of the lack of autonomy that municipal corporations held in relation to the central headquarters of the major parties (Capo Giol, 1991). In any case, it is important to point out that, often, these local parties emerged from personality-driven projects that, in a way, were an updated form of nineteenth century cronyism (Cazorla Pérez, 1995, p. 47 ss). The personality-driven nature of local politics even led the mayor's surname being used to identify the initials of the party. Such was the case of the Grupo Independiente Liberal (Liberal Independent Group), acronymized GIL after its founder's family name, the businessman Jesús Gil, who was mayor of Marbella (1991-2002) and who became the ideological paradigm of the model of tourist exploitation of the Costa del Sol, and by extension, of the Spanish coast (Navarro Jurado et al., 2015, pp. 281-283).

Some authors, from more political positions, point out that these local parties spread in the mid-1990s of the last century supported by the Partido Popular (Peoples' Party) as a political strategic to weaken the PSOE (Socialist Party) which was then in central government (Pérez Royo, 1993). In any case, and in contrast to the state projects of the major parties, local parties always use names that showcase the independent and local character of their political proposals. It is also important to highlight that these local parties emerged within the same ideological framework as that used to approve the Land Liberalization Law (Law 6/1998) of the government of JM Aznar (Rullán Salamanca, 1999). Among other things, it caused the uncontrolled urban development of the territory, excessive increases in property prices and the property bubble that would burst a decade later (Rodríguez López, 2009). An ideological framework that, for the sake of the theoretical perspective of this text, found the idea Residential Tourism to be a means of justifying the unbridled development of the territory (Aledo Tur, 2008). Especially in Spain, where any reference to tourism as a basis for political action provides an indisputable argument, and, at the same time, it relegates any criticism that may be made, to the margins of the ideological and social system (Milano, 2017; Yanes Torrado, 2017). 
However, the purpose of this text is not to once again investigate the intricate relationship that exists between predatory urban planning, property speculation, cases of prevarication and the municipal policies of independent parties in tourist areas. The purpose is to illustrate the process via which the tourism space impacts on the production of social and cultural meanings which help to give sense to daily life. For example, how can we explain the case of the tourist complex on El Algarrobico beach in Carboneras (Almería) where the public rejected the demolition of the building despite the fact that it had been built in a natural park (Europa Press, 2016). Or why the residents of the very small municipality of Villanueva de Gómez (150 inhabitants) in Ávila defend the construction of the macroresort "La Favera" which resulted in the felling of more than 10,000 pine trees, argued that stopping the projects would prevent the development of the town and perpetuate its backwardness (Hernández, 2007). Ultimately, the processes via which that series of symbolic and technical mechanisms that we call tourism acquires, within specific categories, status as a reference which is used to justify property speculation practices and the plundering of the territory as confirmed by some studies (Mantecón, 2012). For various decades, I have maintained that these cases where tourism is presented as a means for development are explained with the production of a tourism imaginary that, through the significative mediation entailed by the conversion of place through tourism space, is imposed as a reference that gives meaning to the reality of insiders (Nogués-Pedregal, 1996).

\section{The case study}

Just like in many tourist destinations on the Spanish coast, in El Puerto de Santa María, the urban development of the 1990s was accompanied by an unbridled game of speculation. Alongside political instability, it let to the emergence in 1991 of a group of independents in the municipal political arena, who had very particular ideas about what future and sustainability meant. Faced with the widespread perception among the population regarding the legislative passivity and neglectful management of previous municipal corporations, and supported by certain groups with very specific commercial and property interests, in the municipal elections of 1991 and in coalition with the Socialist Party (PSOE) the Independientes Portuenses (IP) party took power. This independent political project had been founded around the figure of a former Partido Popular (PP) councillor, and soon acquired characteristics of local populism: from the absolute identification of the party colours with those of the city or vice versa, to the personality-driven implementation of municipal policy and confrontations with the neighbouring cities of Cádiz, Jerez and Puerto Real, also governed by strong personalities. Although this peculiar mayor became famous during the municipal electoral campaign of 1999 by destroying a rose (symbol of socialism) during a meeting, he sealed his continuity in power in the 2003-2007 legislature via an agreement with the once spiteful socialists. In 2006, he was convicted of prevarication and disqualified from holding public office. Faced with the prospect that the deputy mayor of urban planning, second on the election list, could be involved in murky property dealings, and that the third on the list had left the party to become the head of the PP list, the replacement was the fourth on the list who, in turn, had been a PSOE councillor who was a turncoat and then joined IP.

In the municipal elections of March 2007, IP suffered an electoral disaster by finishing third, and the PP emerged as the dominant political force. The mayor who replaced them, a former IP councillor, obtained a stable majority thanks to the support of the only councillor of the Partido Andalucista and the former mayor who was replaced and the head of the IP list, who out of gratitude, took charge again of the responsibilities that ensured a continued 
media presence: the Department of Tourism and Promotion of the City, and the Presidency of the Bullring. This brief description shows the particular characteristics of these types of local parties, which are repeated time and time again in tourist destinations municipalities, and requires an in-depth examination.

Analysis of the specific policies leads us to state that the government of Independientes Portuenses was characterised by a lack of clear policy guidelines, other than shortsighted growth (urban and demographic growth), antiquated cronyism and property speculation. This series of factors encouraged the uncontrolled rise in second homes, with hundreds of hectares of Mediterranean pine, vegetable gardens and fruit trees eradicated - and along with them an entire cultural way of understanding the territory - and altered the spatial perception of the historic centre with a concept of urban gentrification lacking cultural and expressive continuity, as already shown in the eighties in the study on the impact of the "Puerto Sherry" marina on the social perceptions among the young people of El Puerto (Nogués-Pedregal, 1989; Reynier and Tubery, 1988).

\section{Tourism activities in El Puerto}

El Puerto de Santa María (Cádiz) is a town located at the mouth of the Guadalete River and it has 88,430 inhabitants (2017). Thanks to its strategic location in the Bay of Cádiz and its 22 $\mathrm{km}$ of beaches, El Puerto has become a leading national tourist destination and its popularity has spread beyond Andalusia. According to the official statistics of the Regional Government of Andalusia, the city has a hotel capacity of 2,500 beds and its economy is based on the tertiary sector: wholesale and retail trade, professional activities and the hospitality industry.

The tourist reality of the city, closely linked to the healthy medicinal baths, is not a recent phenomenon (Nogués-Pedregal, 1999). The description of Francisco Mariano Nipho (1771) points out that the waters of the Guadalete River "can also be used for general and medicinal baths" (Pérez Fernández, 1994, p. 34). Some decades later, in 1823, the presence of visitors in the area seems to be consolidated, as can be inferred from the following paragraph:

In 1823, El Puerto was favoured by being designated a spa resort, by Infante Don Francisco de Paula and his wife Doña Luisa Carlota, who came accompanied by their sons Don Francisco de Asís and Don Enrique and two young princes, accompanied by their entourage, comprising seventy-two people between nobles and servants, without counting the types of troops bearing all the weapons (Cárdenas, 1903: no page numbers).

The therapeutic benefits of the seawaters of El Puerto soon acquired social importance and renown. Indeed, one of the first works produced in Spain on the benefits of thalassotherapy was the tract Baños de agua de mar del Puerto de Santa Maria (Seawater baths of El Puerto de Santa María) (Cabrera Afonso et al., 1989; Medinilla y Bela, 1880). It can be concluded that the arrival of visitors in the area during summer was already consolidated by midway through the nineteenth century, and imposed a sufficiently different pace so that any seasoned traveller could observe the differences that were established, as outlined in the description of Antoine de Latour in 1858:

El Puerto de Santa María is now a town of eighteen to twenty thousand souls, a town of rest, movement and transit during summer, but during the other seasons, it does not partake in the commercial activity of Cádiz and La Isla (San Fernando). It is surrounded by well-cultivated lands and proudly shows its beautiful wineries to foreigners. The homes have a certain festive air, the streets are clean and its people are bustling and lively (De Latour and Bermúdez, 1986, pp. 98-99). 
Over the years, the summer visitors were consolidated as the distinctive trait that the new productive cycle of El Puerto revolved around. With tourism, the modification of social, cultural and ecological rhythms transform towns into tourist destinations (Boissevain, 1982; Nogués-Pedregal, 2012b). The Council made this clear at the end of the nineties:

At present, it is the most dynamic activity of El Puerto de Santa María. Following the operating model of the coastline, most of the productive resources are allocated to this activity, with the subsequent danger of the dependency for sector that is so vulnerable to crises situations. To show the significant evolution of the sector, it is simply necessary to mention the number of hotel beds. The capacity of 487 in 1973 had risen to more than 2000 in 1992, and most of the beds were in three and four-star hotels (PGOU, 1999, pp. 333-334).

However, tourism has had a presence in municipal plans since the end of the 1960s, as shown by the fact that in all the annual reports produced by the Council, tourism is always referred to in very positive senses and terms:

Activities relating to tourism constitute one of the most important aspects and one that receives the most attention from the Council. Due to its location, its climate, its beaches and general set-up, El Puerto de Santa María offers significant reasons for tourism, which the municipality wants to capitalise on fully. To that end, the aim is to achieve the aim of stable, healthy and profitable tourism, without damaging day tourism and fleeting visits (Memoria, 1975).

The tourism of El Puerto is not however simply a creation that has been designated as an official reality, but rather, long before it attained an unquestionable dominance as a vital phenomenon for the city, there was already a concern for the city's image in relation to the visits of "outsiders". Hence, the establishment of the obligation to annually paint or whitewash façades, with penalties for residents who did not carry out the activity. The measure was targeted at rectifying the state of neglect in the neighbourhoods and the historic quarter. As proof of this, we have included the full text of the first proclamation on this matter.

\section{THE MAYOR OF THIS CITY:}

ANNOUNCES: The fact that the spring festivals are soon taking place in this city, during which it will be visited by many outsiders, makes it necessary to make sure that the façades of the buildings are in a proper state of tidiness. For that purpose, in compliance with the provisions of article 281 of the Current Municipal Ordinances, the owners or administrators of urban properties of urban properties, should carry out repairs or painting of their façades, before 15 April, to ensure that their poor appearance does not detract from the quality that befits the buildings in this city.

Failure to comply with what is stipulated will be sanctioned as civil disobedience with the corresponding sanction. This is made public via this announcement and others of a similar nature for the knowledge of the interested parties.

Puerto de Santa María, 7 March 1947. Ignacio Osborne.

We can see that the city"s image has been one of the greatest tourist assets in the area. However, this vision of the city as inhabitable and appealing fell into disuse when, in its ideological evolution and political practice, the process to expand tourist activities was constituted as the only instrument for economic expansion, and the activities were linked exclusively to property development.
Local politics and urban aesthetics 
JTA

26,1

10
Figure 1.

Map of El Puerto de Santa María, drawn by Miguel de Palacios in 1865. Its delimitation corresponds to the historic urban area protected in 1984

\section{Urban expansion}

Any economic boom is reflected in the boundaries of the city. By comparing the Figure 1 and Plate 1 it is possible to see how up until the decade of the fifties, the urban area of the municipality was maintained within the boundaries established during the 19th century.

Urban expansion in El Puerto was characterised by two specific deeds which had a direct impact on the ideological construction of the city. First, the construction of the neighbourhoods as functional urban units in areas outside of the system and with a difficult transport and communication system that, as in so many other towns and cities, socially and culturally characterises El Puerto.

Second, the total contempt of the historic past, as shown in the continued attacks against the city's architectural heritage, despite the fact that Royal Decree 3038/1980 of 4 December included the designation of the large area of the city that appears in Figure 1 and Plate 1 as an Historic-Artistic District (Plates 2 and 3).

Along with the general decline of primary sectors in industrialised countries as a whole, the main reason for this urban expansion was the functional change that occurred in the land, which went from being farmed, that is to say, productive, to being buildable, that is to say, speculative (Aledo Tur, 2008). The process aimed to offer a solution to the problem of a lack of housing that El Puerto suffered midway through the twentieth century, both because of the increase in inhabitants residing in El Puerto, as well as the constant growth of the summer population as a factor that had a destabilising effect on the offer-demand relationship.

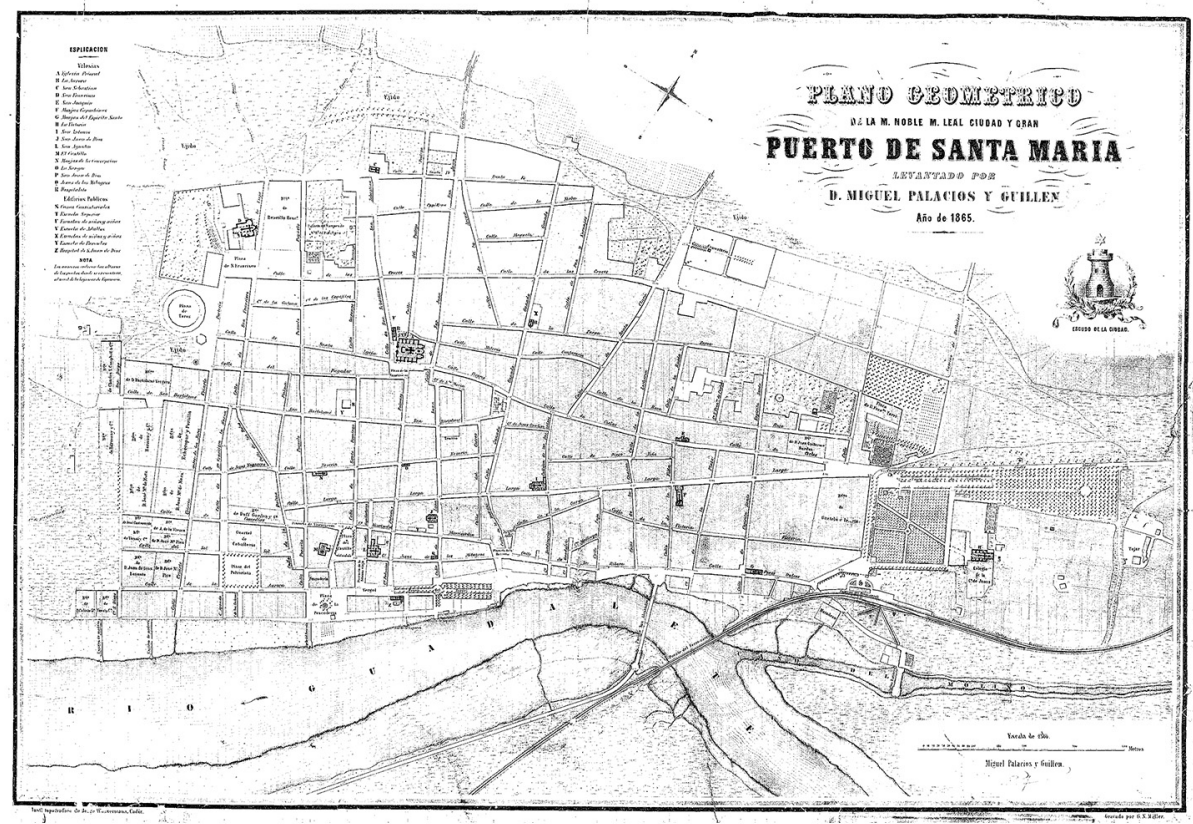

Source: The city council department of Historical Heritage in El Puerto of Santa María 


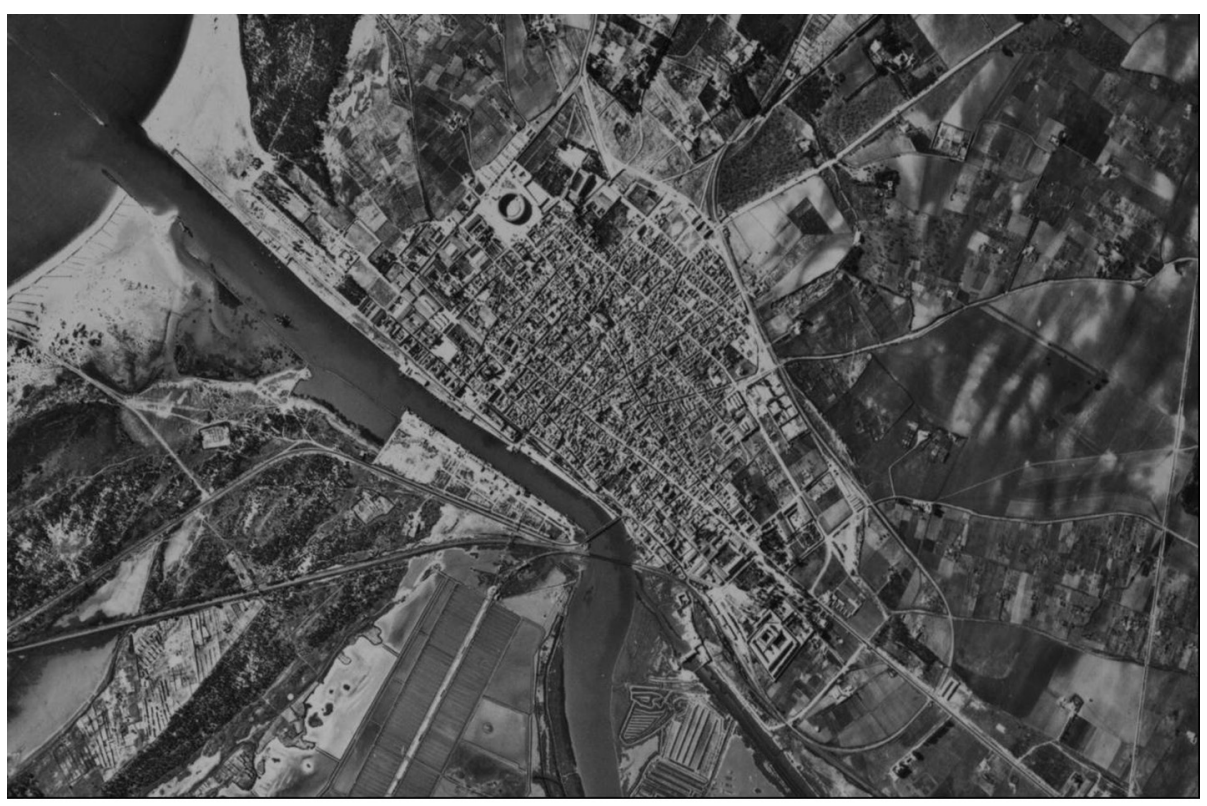

Source: The city council department of Historical Heritage in El Puerto of Santa María

The expansion occupied the land outside of the historic-artistic protected area, beginning with the construction of the Crevillet and Las Nieves neighbourhoods at the end of the 1950s, both located on the outskirts and outside of the urban centre. However, as you would expect in a sector like urban planning, where speculation is normally very prominent, the greatest and most uncontrolled building activity took place in the coastal area. The sixties were a key time for the urban planning of beaches, as can be seen in the reports by the Council in the section relating to building permits, which rose from 82 permits in 1971 to 267 permits in 1980, and in the budgets allocated to works developed by the Council, increasing from 215.4 million pesetas in 1971 to almost 2.5 billion pesetas in 1980 .

However, urban development in El Puerto was not limited to the area along the coastline, there was very notably development in the Northern zone (Urbaluz and Vallealto), although the interests of these residents differ to those who purchase their property on the coast. The residency of the former group, as residents of the city, is permanent; on the contrary, the properties purchased by the latter group are almost exclusively used as second homes or as rental properties.

Urban toponymy have a strong anthropological value, as they show the historic-cultural construction of a social environment: the city. Whenever new streets and squares are created, names are used that to a greater or lesser extent, make sense to residents. The signs of the different streets, areas and zones of the municipality are significant in that they have the capacity to evoke a shared past: the world of wineries, the sea, countryside, professions, places, etc.

However, the development process of the resort makes it necessary for the new names to not refer to the symbolic and cultural world of the inhabitants. Instead, they must refer to the clichés of our western civilisation. Therefore, one of the consequences of the significant transformation of the ground into building land is the cultural rupture produced by the
Local politics and urban aesthetics

Plate 1. Aerial view in the early 1950s. It is easy to distinguish the

Bullring. The urban area has the same limits as the map of Palacios (1865) 
JTA

26,1

12

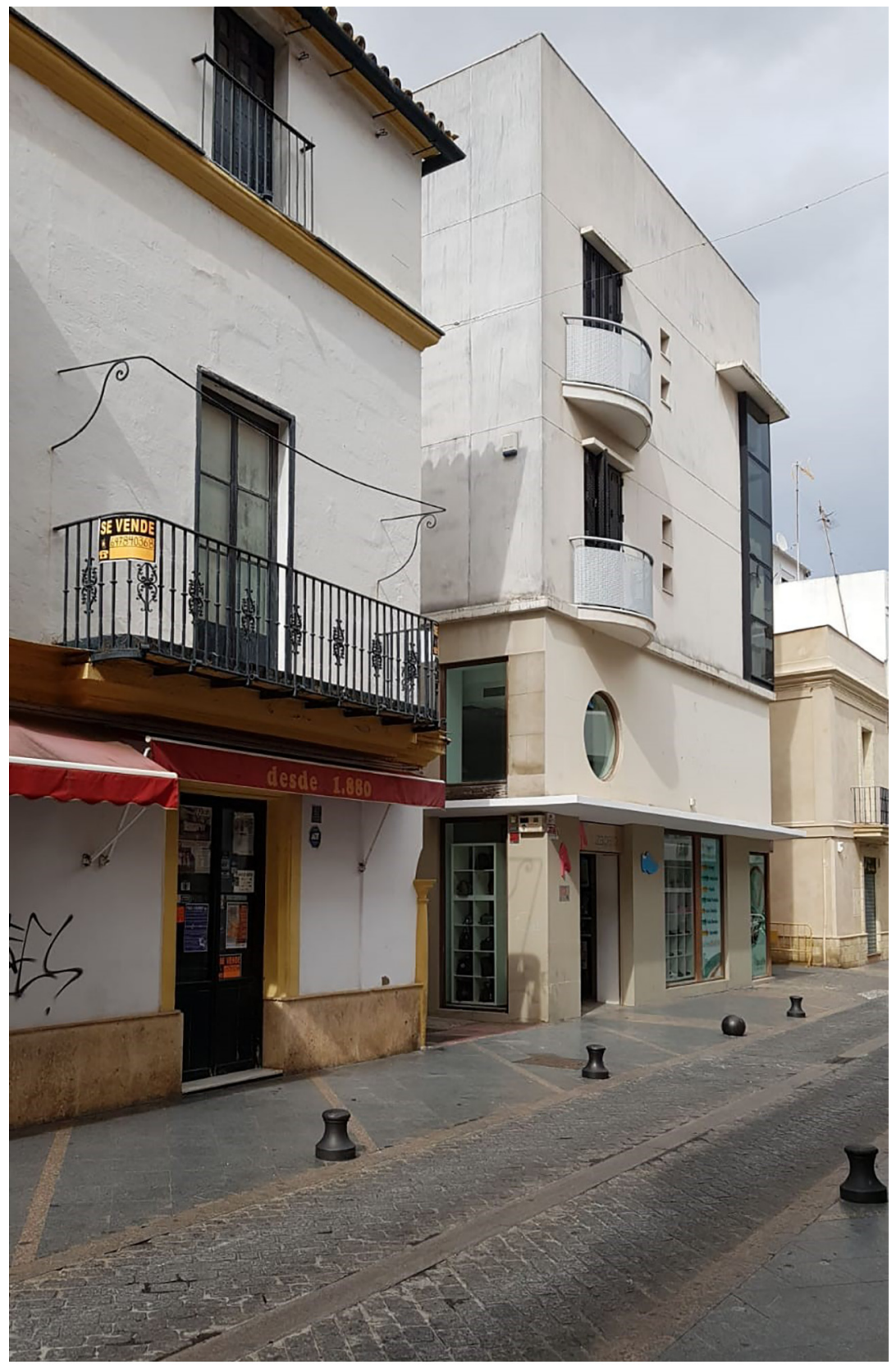

Plate 2.

An example of an architectural break in the historical centre

Source: Author 


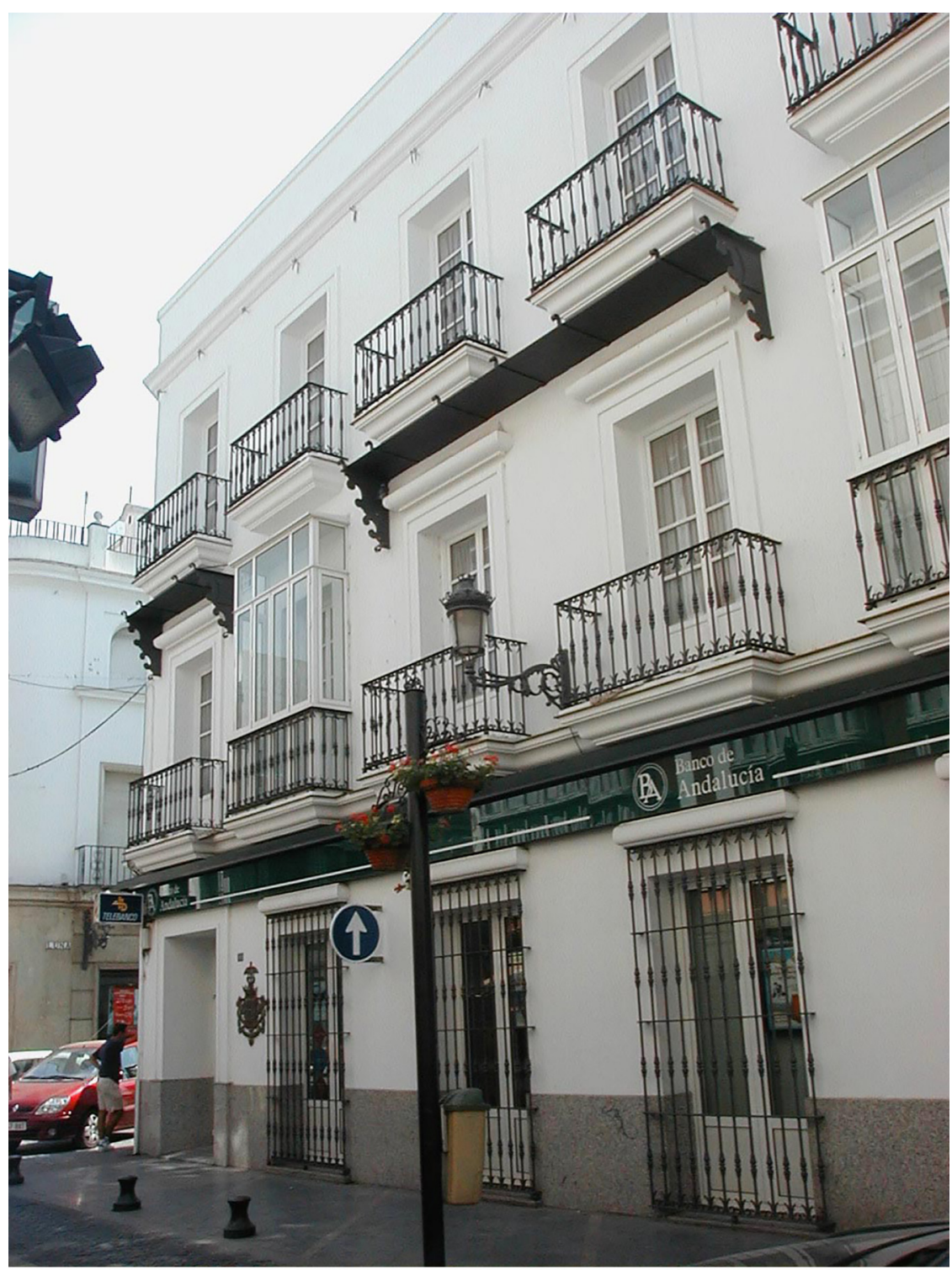

Source: Author
Local politics and urban aesthetics
Plate 3.

Example of integration and respect for aesthetic coherence in a new building. Located just hundred meters from the building of Plate 2

symbolic appropriation of the developed places, which takes place through the prism of the new development discourse via the naming of the land.

The names of the new streets do not make reference to the memory of the place anymore. These are empty terms, which ultimately only verbalise the process via which the place is perceived, understood and managed in accordance with logic outside of that of its own 
reproduction, and which means that the reality of the resident is experienced, interpreted and understood through the perceptual world of the visitor. In other words, tourism imaginary comprised values, narratives and iconographies that provide meaning, serve as a reference and impact on the understanding of social practices that occur in the tourism environment. This is a process that I call "conversion of place through the significative mediation of tourism space" (Nogués-Pedregal, 1995, 2012a).

From this perspective, tourism space is a distinct referential frame; it is a mediator in the production of meaning with a clear nod to Chadefaud's (1987) perspective. It allows examination of the lived experiences of the dialogue between the macro-social structures, theorised as constrictive, and the micro-social actions, considered to bear enabling properties. As a heuristic tool, the notion tourism space enables the study of culture: that series of practices that acquires its sense within a specific group, gives meaning to its social life and distinguishes it from other groups, and "that we can use to talk about difference" (Appadurai, 1996, p. 13). It also correlates somehow with Michel Picard's proposal:

One should pay attention to what is at stake with the new meaning a culture acquires for its bearers by being promoted as a tourist attraction. In other words, to the extent that it alters the view that a society takes of itself, tourism reveals the way the native population relates to its memories, to its traditions, to its values - in short, to its identity (Picard, 1995, p. 46)

In addition, in the case that we are analysing, this is shown very clearly in the conception of urban planning shown by local parties.

\section{The fracture of cultural meaning}

The processes of significative mediation in tourist environments are characterised, firstly, by the appropriation of uniformities from outside the place; that is to say, through the incorporation of elements of great symbolic value for the ideological construction of reality, but which fracture the continuity of the ecological-cultural sense of a human group on the territory. These external elements are shaped as the references of an imaginary that gives meaning to the tourist experience, but forget that

On a space, cultures build their territories, they marked them with deictics, toponyms and prosoponyms, and qualify them in terms of beliefs, values, ideologies, and give them meaning. They thus turn them into places when they beautify or deteriorate them, live in them and remember them (Mandly Robles, 2002, p. 108).

The text that heads this article may be a fable on the lack of attention that is paid and the lack of knowledge about the importance of the historic production of meaning to ensure the social development of groups. The case of the fountain shows how often urban growth ends up being accepted as the only possible path for local development to end up taking in tourist contexts, and it prevents the emergence of different projects that are linked to the cultural peculiarities of the place. However, there is also resistance and opposition to the process, especially, with regard to land-use (Boissevain and Selwyn, 2004). The dialogic process that the tourist area emerges from does not necessarily entail the total disappearance of the culture of the place. On the contrary, both manifestations of the cultural (native and visiting) interact and blend with one another to the point that they are merged, as shown in the case of Bali, where the authorities talk of kebudayaan pariwisata to refer to that state characterised by an axiological confusion between what belongs to culture and what pertains to tourism" (Picard, 1995, p. 57). Hence, the importance of shifting the anthropological study of tourism as a discreet phenomenon, and reintroducing the centrality of social and cultural practices in tourism contexts. 
However, the matter at hand is not a fable. The following text taken from the official website of the City Council during the 1993-2003 legislature is a good example of this significant transformation process, and how the place ended up being perceived, considered and governed as a tourist area:

One of the main assets of El Puerto de Santa María is significantly a natural resource that this city possesses: its beaches.

Beaches of fine, golden sand which, along with the shining sun and fresh, crystalline waters, create a perfect setting for spending an unforgettable time in El Puerto.

Youthful and relaxed atmospheres, more family-friendly beaches for the enjoyment of children and adults, hidden spots where it is possible to enjoy a day at the beach in complete freedom. Lively beaches, private beaches.

Moreover, in El Puerto de Santa María we go further and consider the entire infrastructure that makes our sunny days more comfortable and relaxed, to be "beaches" too (Figure 2).

The convincing nature of the last paragraph makes any comment unnecessary, especially if illustrated with images that show the effective presentation of a city centre not as the place produced by the history that it is, but rather as a predominant tourist area saturated with tourism indicators.

However, the best marker of a transformation of a place into a tourist territory is, the indicators that saturate the most attractive areas of cities with tourist information that visually pollute them (Plate 4).

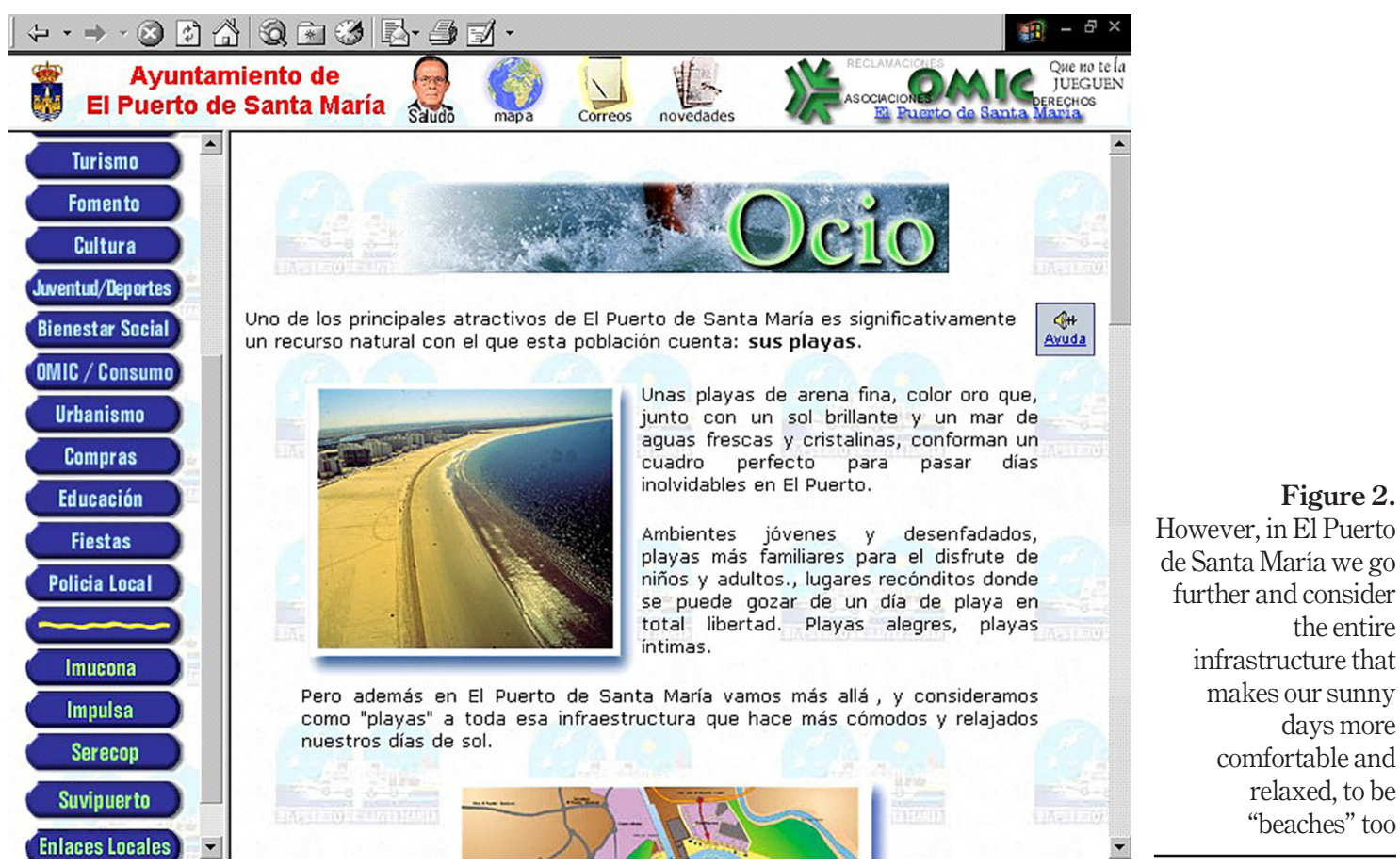

Local politics and urban aesthetics 
JTA

26,1

16

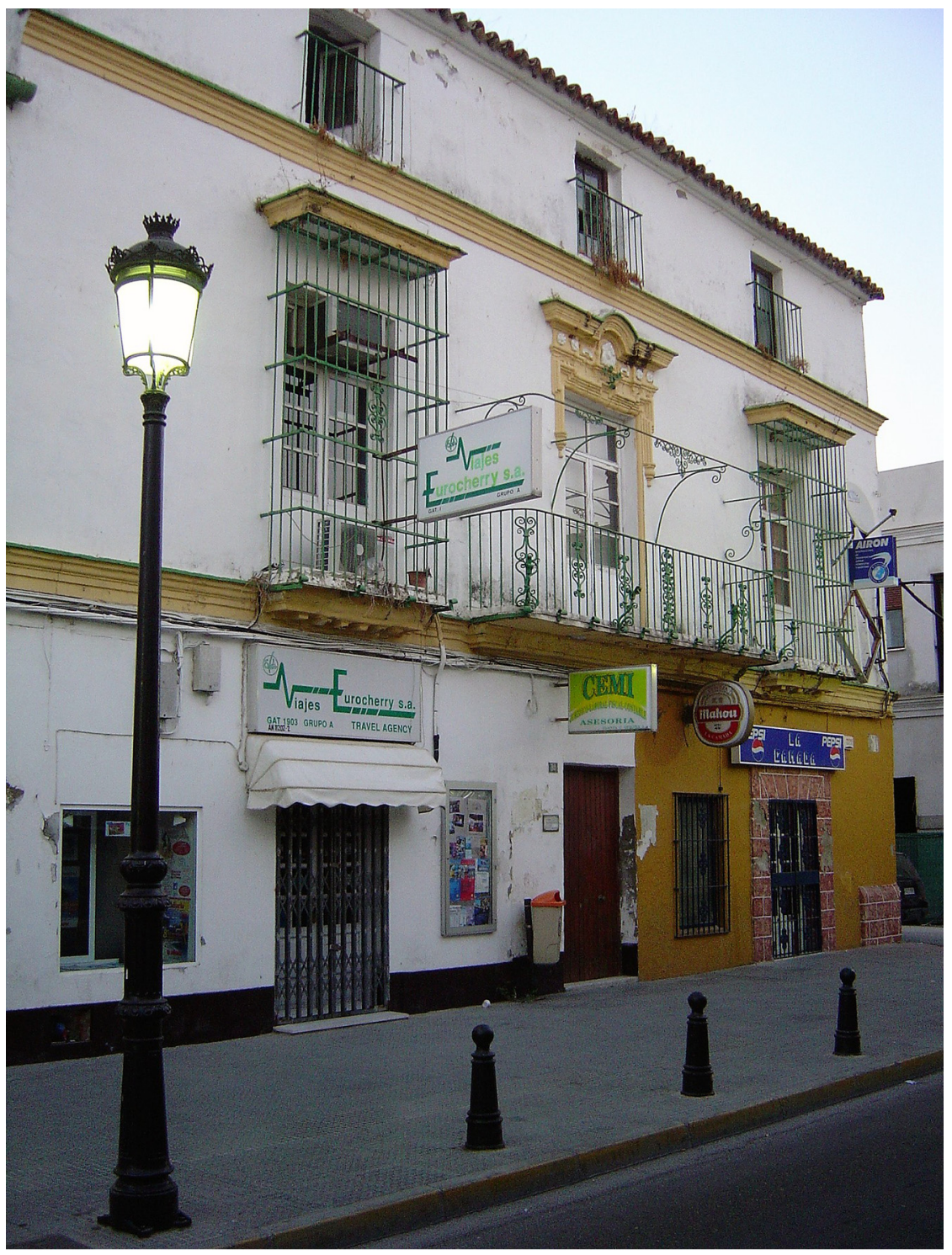

Plate 4.

Historical façades covered by tourism indicators

Source: Author

Second, the incorporation of external references results in the loss of the anchors of memory. A loss that, in terms of local politics, generates political instability and, thus, the optimal conditions for the emergence of political projects characterised by ideological poverty and decisive assertiveness in all matters relating to urban planning and tourist development. 
Details such as the diversity of paving used in the historic-artistic district and the installation of makeshift street lights indicate that, depending on the tourist contexts, the symbols of modernity discussed are incorporated into the city against any attempt to link the group to its own history (Plate 5). An ethnographic reality that shows, on one hand, the
Local politics and urban aesthetics

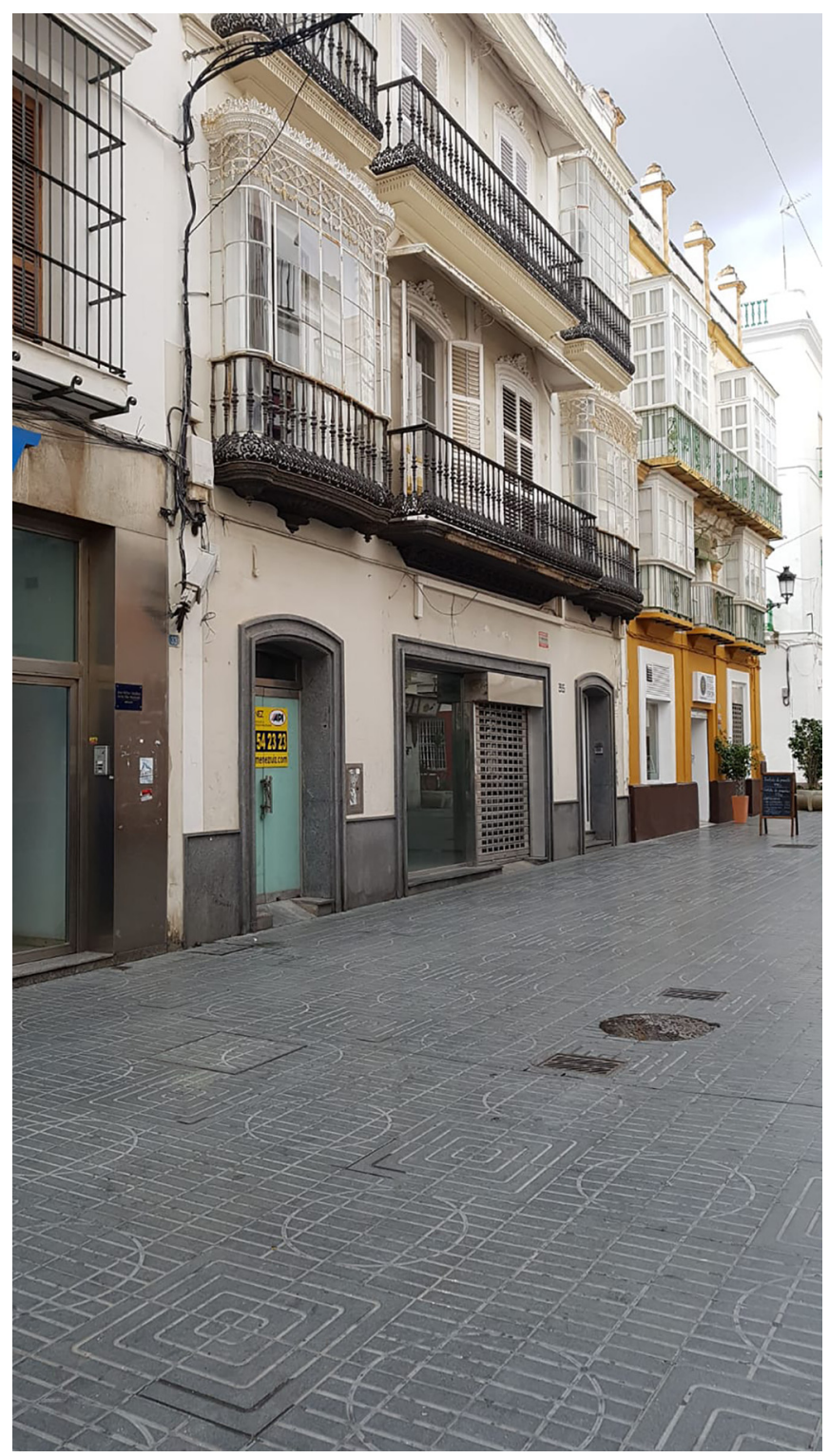

Plate 5.

A view of the commercial street downtown. The cobblestone has been replaced by the pavement of any promenade of any coastal town, which strikingly differs with the historical architecture

Source: Author 
JTA

26,1

18

\section{Plate 6.}

The arcades are one of the most characteristic architectural features of the city large amount of ignorance towards the economic potential of cultural heritage, and on the other hand, the strong inferiority complex that characterises these policies with regard to the promising attractions of the fast-paced urban planning process.

Third, the transformation of the place into a tourist territory is manifested in the prevalence given to instrumental and commercial values over one's own aestheticexpressive values. The series of activities which, for convenience sake, we call tourism is one of the most perfect creations of the capitalist mode of production. In its perfection it has marketed, by turning intangibles into heritage, the last strongholds of the production and reproduction of meaning, turning the transformative power of culture into a metacultural product: cultural heritage (García García, 1998; Kirshenblatt-Gimblett, 2014). In the case of El Puerto de Santa María, this snub of the aesthetic value of traditional architecture is paradoxically shown by concealing the most iconic and attractive architectural and decorative elements in the city (Plates 6 and 7).

A variant of the concealment of heritage assets is, fourth, the occupation of public space. The transformation of old public places into tourist settings from where visitors draw their motivation and satisfaction for trips requires the economic exploitation of a tourist territory to be carried out without control. Consequently, it collides head on with any urban planning regulations or political project that, in the interests of heritage protection and the public use of the city, combats these types of practices.

Deriving from the process of cultural dismantling, there is, in fifth place, what misled MacCannell when he coined his famous term "staged authenticity". The increasing concern by a section of a more urbane business community to recover traditional flavours in the form of wineries, inns, grills, kitchens, inns, stores and backroom shops, results in names that

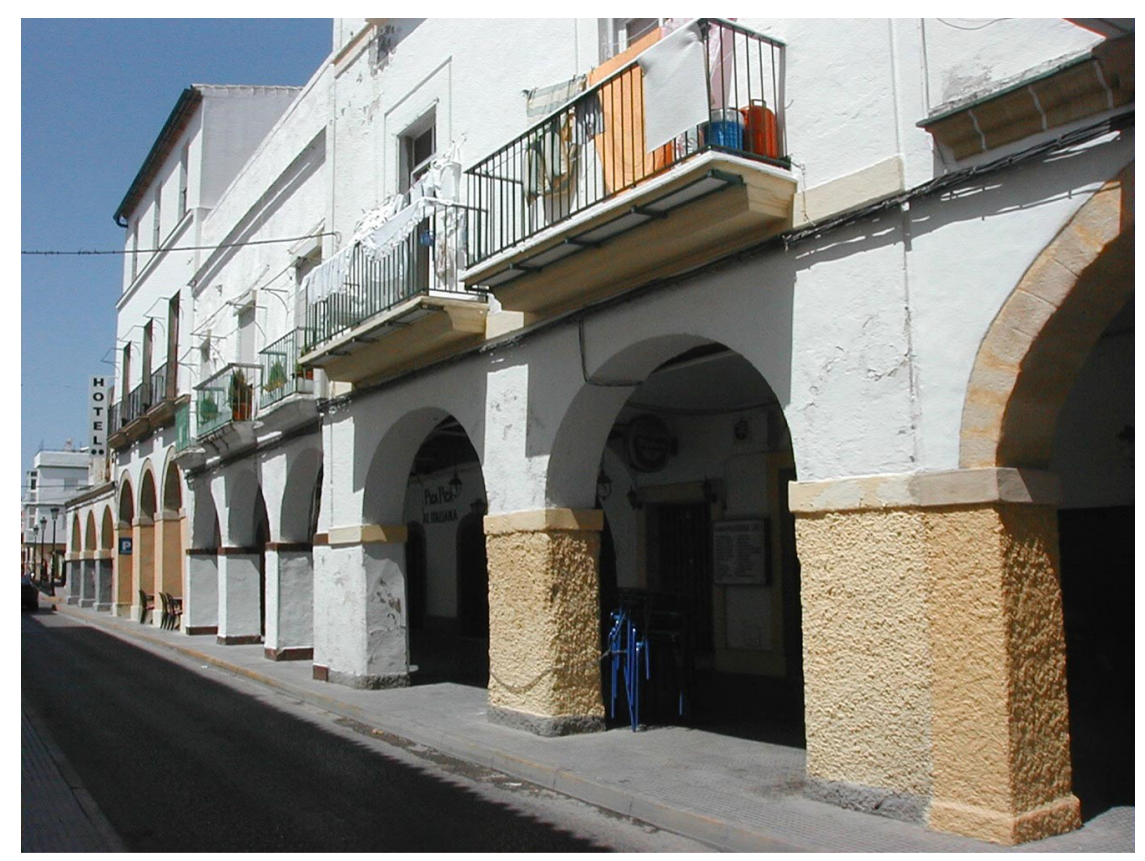

Source: Author 


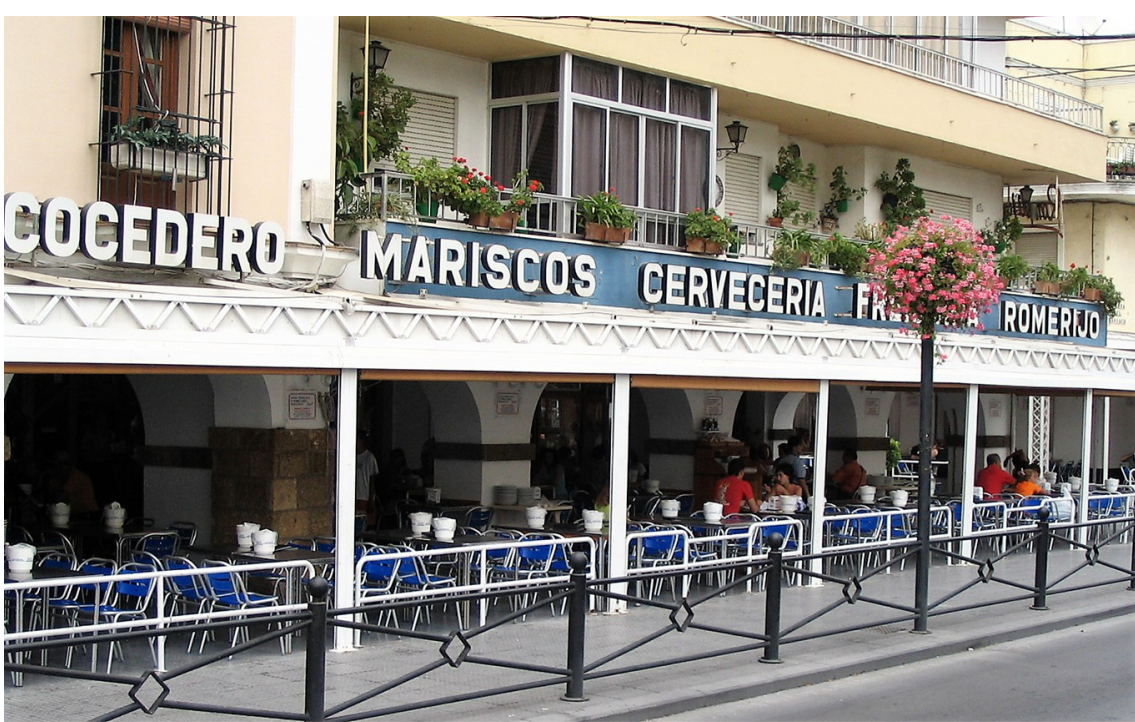

Source: Author
Local politics and urban aesthetics

Plate 7.

The arcades of the famous Romerijo ${ }^{\circledR}$ seafood restaurant are the best example of the total

"conversion of place through tourism space"

evoke characters from the collective imagination that endorses tourism as something that is desired, and that can be found in any tourism context: El Fogón del tio Curro (Uncle Curro's Kitchen), La Bodega de la Juana, (Juana's Winery), El Asador de Abajo (The Downstairs Grill), La Trastienda de la Lola (Lola's Backroom) and La Tasca del Soberao (The Attic Tavern). With a few exceptions, the gastronomy of these new-age taverns (nueva mesoneria) restores the aroma of the delicatessens of inland areas and the coast, through cold meats, cured porks, traditional crops, cheeses, rustic bread, all kinds of cured products and preserves, charmingly packaged in glass jars with chequered cloths, tied with the delicate string of old packages and aged labels. This is the kingdom of homemade products. This sincere concern for restoring an imaginary culinary tradition does not however manifest itself in respect for the urban environment.

Tourism activity, as an industry of the senses, favours that which can be acquired via a commercial relationship, that is to say, that which, in the narrowest sense of the term, can be consumed: accommodation, entertainment, sustenance and transport. Thus, the safeguarding of architectural heritage for visual consumption in tourist contexts, ideologically, depends on the parallel development of an industry that satisfies the other meanings, and makes the investment in the conservation and restoration of cultural heritage profitable. Thus, in El Puerto de Santa María, because of the lack of a clear political strategy, the process has been inverted and in situ consumption has been favoured over sustainable enjoyment.

However, there are also signs that display somehow a more civic behaviour and incorporate aesthetic principles that combine respect for the urban environment with the desired economic activity that will invigorate the historic centre of El Puerto (Plate 8).

Sixth, the ideological uniformity involved in this modality of tourism that is governed solely by the laws of the market (quality, competitiveness, visitor satisfaction, seasonality, consumption, etc.), defines the territories "from the outside and outward" and, by doing so, impoverishes the social dynamic and encourages the emergence of demagogic political 
JTA

26,1

20

\section{Plate 8.}

The recreation of traditional architecture in transparent awnings with the typical Andalusian trellis

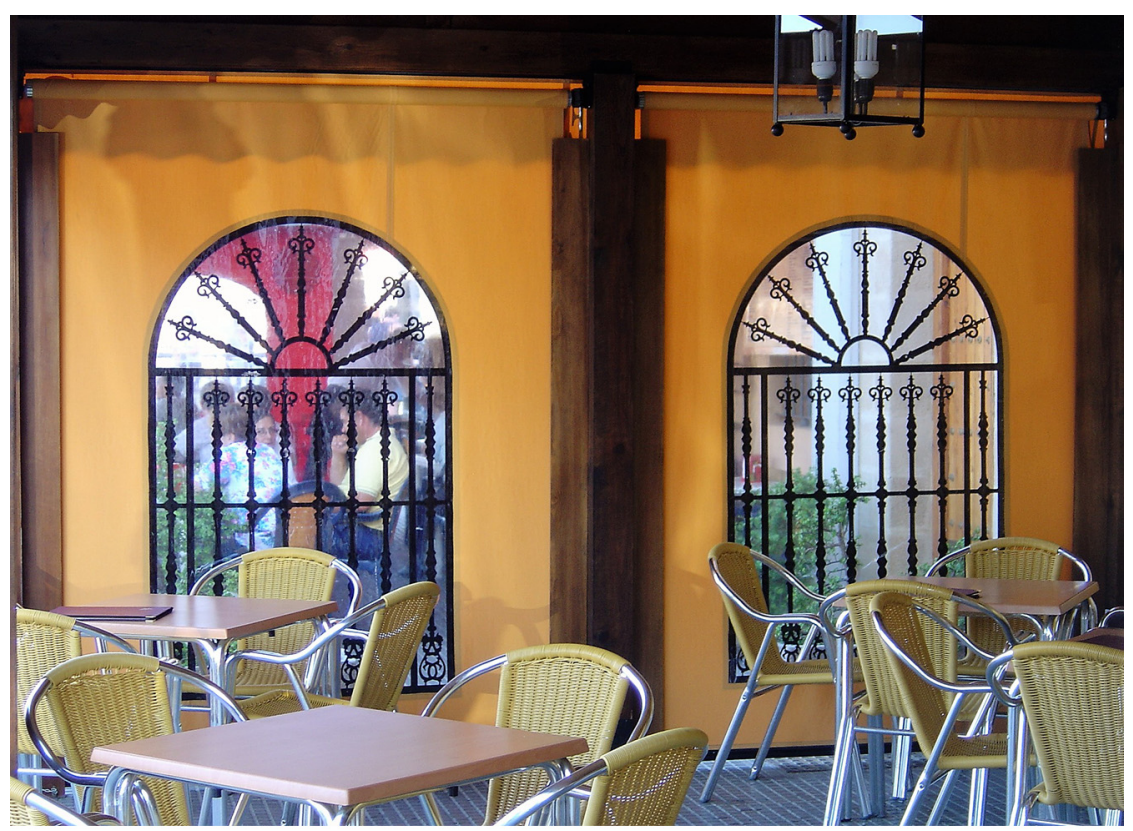

Source: Author

proposals that only offer easy solutions to complex problems. In El Puerto de Santa María the absolute hegemony of tourism space as an ideological mediator on the perception of the city has resulted in a policy of indifference towards the places that once mattered; though at present, viewed from the prevalent perspective of commerce, do not have any apparent value.

\section{Conclusion}

This study uses a socio-anthropological approach to analyse the link between tourism processes, the emergence of a new chronotope relationship between the past, present and future, the rise of populist political projects at a local level, and how this manifests itself in the shaping of a planning-architectural space of a consolidated tourist destination. To explain this process, the model of the conversion of place through the significative mediation of tourism space is presented as an analytical working hypothesis.

It is explained that this transformation has two main characteristics. First, the prevalence of instrumental and commercial values over local aesthetic-expressive values is manifested in the incorporation of uniformities from outside the place and the consequent loss of the anchors of memory. On the other hand, the definition of territories "from the outside and outward" encourages the occupation of public space and the adoption of aesthetic criteria targeted at tourism imaginaries and produces new urban attributes.

The working hypothesis used to explain this case study shows that certain tourism developments tend to uproot the anchors of collective memory and to fracture cultural heritage. Consequently, social ties are dismantled and social relations become fragile what facilitates the emergence os populist political projects. 


\section{Notes}

Local politics

$1 \mathrm{http}: / /$ statistics.unwto.org/

2 www.wttc.org/-/media/files/reports/economic-impact-research/regions-2018/world2018.pdf

\section{References}

Aledo Tur, A. (2008), "De la tierra al suelo: la transformación del paisaje y el nuevo turismo residencial", Arbor. Ciencia, Pensamiento y Cultura, Vol. 184 No. 729, pp. 99-113. https://doi.org/10.3989/ arbor.2008.i729.164

Aledo Tur, A., Loloum, T., Ortiz, G. and García-Andreu, H. (2013), "El turismo residencial internacional en el nordeste de Brasil: un análisis de partes interesadas”, Revista Española de Investigaciones Sociológicas (REIS), Vol. 142 No. 1, pp. 3-23, available at: www.reis.cis.es/ REIS/PDF/REIS_142_011365511019131.pdf

Appadurai, A. (1996), Modernity at Large: Cultural Dimensions of Globalization, University of Minnesota Press, Minneapolis.

Baron-Yelles, N. (2010), "Les Espagnols face à la corruption urbaine”, Géographie et Cultures, No. 74, pp. 43-54, available at: https://doi.org/10.4000/gc.1739

Benito, B., Guillamón, M.-D. and Bastida, F. (2015), "Determinants of urban political corruption in local governments", Crime, Law and Social Change, Vol. 63 Nos 3/4, pp. 191-210, available at: https:// doi.org/10.1007/s10611-015-9563-9

Boissevain, J. (1982), "Variaciones estacionales sobre algunos temas mediterráneos”, Ethnica, Vol. 18, pp. 53-58, available at: https://dialnet.unirioja.es/servlet/articulo?codigo $=1441797$

Boissevain, J. and Selwyn, T. (Eds). (2004), Contesting the Foreshore: Tourism, Society, and Politics on the Coast, Amsterdam University Press, Amsterdam.

Brahmasrene, T. and Lee, J.W. (2017), "Assessing the dynamic impact of tourism, industrialization, urbanization, and globalization on growth and environment in Southeast Asia", International Journal of Sustainable Development and World Ecology, Vol. 24 No. 4, pp. 362-371, available at: https://doi.org/10.1080/13504509.2016.1238021

Cabrera Afonso, J.R. Márquez Espinos, C. and Herrera Rodríguez, F. (1989), “Joaquín Medinilla y Bela y su opúsculo ‘Baños de mar del Puerto de Santa María' (1880)”, Revista de Historia de El Puerto, Vol. 2, pp. 91-100, available at: https://dialnet.unirioja.es/servlet/articulo?codigo=1441797

Capo Giol, J. (1991), "Elecciones muncipales pero no locales", Reis: Revista Española de Investigaciones Sociológicas, Vol. 56, pp. 143-166, available at: https://dialnet.unirioja.es/servlet/articulo?codigo= 249408

Cárdenas, J. (1903), Reseña Histórica Descriptiva de la M.N. y M.L. Ciudady Gran Puerto de Santa María (Copia meca), Archivo Municipal de El Puerto de Santa María, El Puerto de Santa María.

Cazorla Pérez, J. (1995), "El clientelismo de partido en la España de hoy: una disfunción de la democracia”, Revista de Estudios Políticos, Vol. 87, pp. 35-52, available at: https://dialnet.unirioja. es/servlet/articulo?codigo $=597911$

Chadefaud, M. (1987), Aux Origines du Tourisme Dans Les Pays de L'Adour (Du Mythe à l'espace: un Essai de Géographie Historique), Département de géographie et d'aménagement de l'Université de Pau et des Pays de l'Adour, Pau.

Das, J. and Dirienzo, C. (2010), "Tourism competitiveness and corruption: a cross-country analysis", Tourism Economics, Vol. 16 No. 3, pp. 477-492, available at: https://doi.org/10.5367/ 000000010792278392

Díaz Fernández, J.A. (2009), Turismo y políticas de desarrollo local: el estratégico papel de la administración municipal, Deputación Provincial da Coruña, A Coruña.

De Latour, A. and Bermúdez, L. (1986), La Bahía de Cádiz, Diputación Provincial de Cádiz, Cádiz. 
Europa Press (2016), "El alcalde de Carboneras: 'La decisión del Algarrobico cercena el futuro de la comarca", Europa Press, 18 February, available at: www.europapress.es/andalucia/almeria-00350/ noticia-alcalde-carboneras-decision-algarrobico-cercena-futuro-comarca-20160218171558.html

Figueira Martins, J.C. (2011), "Tourism urbanization in Algarve (1965-2004)", Tourism and Management Studies, Vol. 2, pp. 1047-1050, available at: www.redalyc.org/html/3887/ 388743868013/

García García, J.L. (1998), "De la cultura como patrimonio al patrimonio cultural”, Politica y Sociedad, Vol. 27, pp. 9-20, available at: https://dialnet.unirioja.es/servlet/articulo?codigo $=154505$

Gladstone, D.L. (1998), "Tourism urbanization in the United States", Urban Affairs Review, Vol. 34 No. 1, pp. 3-27, available at: https://doi.org/10.1177/107808749803400101

Gravari-Barbas, M. and Guinand, S. (Eds). (2017), Tourism and Gentrification in Contemporary Metropolises: International Perspectives, Routledge, London.

Hanningan, A.J. (1995), “Tourism urbanization”, Current Sociology, Vol. 43 No. 1, pp. 192-200, available at: https://doi.org/10.1177/001139295043001016

Hernández, N. (2007), "El anhelo de Villanueva de Gómez", El Norte de Castilla, 22 October, available at: www.elnortedecastilla.es/20071022/castilla-leon/anhelo-villanueva-gomez-20071022.html

Hernández-Ramírez, J. (2015), "El turismo como objeto de estudio. Análisis de la producción bibliográfica de los antropólogos españoles del turismo", Pasos. Revista de Turismo y Patrimonio Cultural, Vol. 13 No. 2, pp. 305-331, available at: https:/dialnet.unirioja.es/servlet/ articulo?codigo $=5089492$

Hiernaux, D. and González, C.I. (2014), "Turismo y gentrificación: pistas teóricas sobre una articulación”, Revista de Geografía Norte Grande, Vol. 58, pp. 55-7010.4067/S071834022014000200004, available at: https://doi.org/10.4067/S0718-34022014000200004

Huete Nieves, R., Mantecón Terán, A. and Mazón Martínez, T. (2008), ¿¿De qué hablamos cuando hablamos de turismo residencial?”, Cuadernos de Turismo, Vol. 22, pp. 101-121, available at: https://dialnet.unirioja.es/servlet/articulo?codigo $=2783558$

Jerez Darias, L.M., Martín Martín, V.O. and Pérez González, R. (2012), “Aproximación a una geografía de la corrupción urbanística en España”, Ería. Revista cuatrimestral de geografía, Vol. 87 No. 87, pp. 5-18, available at: https://dialnet.unirioja.es/servlet/articulo?codigo=4004228

Jiménez, J.L., Nombela, G. and Suárez-Alemán, A. (2017), "Tourist municipalities and local political corruption”, International Journal of Tourism Research, Vol. 19 No. 5, pp. 515-523, available at: https://doi.org/10.1002/jtr.2124

Jurdao Arrones, F. (1992), “La ideología del turismo”, Del Eurofelipismo al Desierto, Endymion, Madrid, pp. 273-289.

Kirshenblatt-Gimblett, B. (2014), "Intangible heritage as metacultural production", Museum International, Vol. 66 Nos 1/4, pp. 163-174, available at: https://doi.org/10.1111/muse.12070

Luo, J.M., Hanqin, H., Goh, C. and Wang, D. (2015), "An analysis of tourism development in China from urbanization perspective", Journal of Quality Assurance in Hospitality and Tourism, pp. 1-21, available at: https://doi.org/10.1080/1528008X.2015.1016594

Mandly Robles, A. (2002), “Espacios, lugares, transparencias”, in Luna, M. (Ed.), La Ciudad en el Tercer Milenio, Universidad Católica San Antonio, Murcia, pp. 109-132.

Mantecón, A. (2012), "El nexo entre urbanización y turismo. Análisis de la opinión pública”, Papers: Revista de Sociologia, Vol. 97 No. 1, pp. 249-272, available at: https:/dialnet.unirioja.es/servlet/ articulo?codigo $=3846225$

Mantecón, A. (2017), "El turismo residencial no existe. Revisión de un concepto y crítica de su función ideológica”, Cuadernos de Turismo, pp. 40510.6018/turismo.40.310041, available at: https://doi. org/10.6018/turismo.40.310041

Mason, P. (2003), Tourism Impacts, Planning and Management, Butterworth-Heinemann, Oxford. 
Medinilla y Bela, J. (1880), Baños de agua de mar del Puerto de Santa María, El Puerto de Santa María, El Rey, Caire, impresor de Ca de S.M.

Memoria (1975), Memoria del Ayuntamiento, El Puerto de Santa María, Cádiz.

Milano, C. (2017), "Turismofobia: cuando el turismo entra en la agenda de los movimientos sociales", Marea Urbana. Revista de la Taula Veïnal d'Urbanisme de Barcelona, Vol. 1, pp. 5-8, available at: https://mareaurbanabcn.wordpress.com/2017/04/25/turismofobia-cuando-el-turismo-entra-en-laagenda-de-los-movimientos-sociales/

Navarro Jurado, E., Thiel Ellul, D. and Romero Padilla, Y. (2015), "Periferias del placer: cuando turismo se convierte en desarrollismo inmobiliario-turístico", Boletín de la Asociación de Geógrafos Españoles, Vol. 67 No. 67, pp. 275-302, available at: https:/dialnet.unirioja.es/descarga/articulo/ 5035577

Navarro Yáñez, C.J. (1997), "El nuevo localismo democrático: análisis descriptivo de algunas tendencias", Gestión y Analisis de Politicas Públicas, Vol. 9, pp. 95-104, available at: https:// dialnet.unirioja.es/servlet/articulo?codigo $=186133$

Nogués-Pedregal, A.M. (1989), "Sobre un estudio antropológico de la Universidad de Québec (I and II)", Diario de Cádiz, 5 October.

Nogués-Pedregal, A.-M. (1995), Estudio socio-antropológico sobre aspectos relacionados con el turismo en Zahara de los Atunes. La configuración de la realidad: anfitriones, huéspedes y antropólogo, Phd dissertation, Universidad de Sevilla, Sevilla, available at: https://dialnet.unirioja.es/servlet/exttes?codigo $=23889$

Nogués-Pedregal, A.M. (1996), "El concepto de espacio turístico y la andalucización folklórica de España”, Dos Algarves, Vol. 1 No. 1, pp. 24-29, available at: www.dosalgarves.com/images/ dosalgarves_1.pdf

Nogués-Pedregal, A.-M. (1999), "Una aproximación desde la antropología a la historia del turismo portuense como estrategia de desarrollo local”, Revista de Historia de El Puerto, Vol. 23, pp. 31-51, available at: https://dialnet.unirioja.es/servlet/articulo?codigo $=1414747$

Nogués-Pedregal, A.-M. (2012a), "Conclusion: Sociocultural nature and context of tourism”, in Nogués Pedregal, A.M. (Ed.), Culture and Society in Tourism Contexts, Vol. 17, pp. 181-208, Emerald Group Publishing, Bingley, available at: https://doi.org/10.1108/S1571-5043(2012)0000017011

Nogués-Pedregal, A.-M. (2012b), "El cronotopo del turismo: espacios y ritmos", Revista de Antropología Social, Vol. 21 No. 21, pp. 147-171, available at: https://doi.org/10.5209/rev_RASO.2012.v21.40053

Nogués-Pedregal, A.-M., Travé-Molero, R. and Carmona-Zubiri, D. (2017), “Thinking against 'Empty shells' in tourism development projects", Etnološka Tribina, Vol. 47 No. 40, pp. 88-108, available at: https://doi.org/10.15378/1848-9540.2017.40.02

Pack, S.D. (2006), Tourism and Dictatorship. Europe's Peaceful Invasion of Franco's Spain, Palgrave MacMillan, New York, NY, available at: https://doi.org/10.1057/9780230601161

Palamalai, S. and Kalaivani, M. (2016), "Tourism expansion, urbanization and economic growth in India: an empirical analysis", IUP Journal of Business Strategy, Vol. 13 No. 4, pp. 36-49.

Pérez Fernández, E. (1994), "Baños en la ría del Guadalete”, Pliegos de la Academia, No. 10, pp. 34-38.

Pérez Royo, J. (1993), "Partidos y pandillas”, El País, 26 May, available at: elpais.com/diario/1993/05/26/ espana/738367235_850215.html

PGOU (1999), Revisión del Plan General de Ordenación Urbana, El Puerto de Santa María, Cádiz.

Picard, M. (1995), "Cultural heritage and tourist capital: cultural tourism in Bali", in Lanfant, M.F., Allock, J. B. and Bruner, E. M. (Eds), International Tourism: Identity and Change, pp. 44-66, Sage Publications, Londres.

Reynier, C. and Tubery, A. (1988), "Les jeunes et le tourisme: une analyse des systèmes de valeurs (Puerto Santa Maria, Espagne)", Loisir et Société/Society and Leisure, Vol. 11 No. 1, pp. 159-168, available at: https://doi.org/10.1080/07053436.1988.10715296
Local politics and urban aesthetics 
JTA

26,1

Rodríguez López, J. (2009), "El colapso de la burbuja inmobiliaria y sus consecuencias", Temas para el debate, Vol. 177, pp. 76-78, available at: https://dialnet.unirioja.es/servlet/extart?codigo=3027398

Romero Martínez, J.M., Romero Padilla, Y. and Navarro Jurado, E. (2015), “Atributos urbanos contemporáneos del litoral mediterráneo en la crisis global: caso de la zona metropolitana de la Costa del Sol”, Scripta Nova. Revista Electrónica de Geografía y Ciencias Sociales, Vol. 19 No. 515, pp. 741-798, available at: https://dialnet.unirioja.es/servlet/articulo?codigo $=5347446$

Rullán Salamanca, O. (1999), "La nueva Ley del Suelo de 1998 en el contexto del neoliberalismo postmoderno”, Investigaciones Geográficas, Vol. 22, pp. 5-22, available at: https://dialnet.unirioja. es/servlet/articulo?codigo $=111703$

Saha, S. and Yap, G. (2015), "Corruption and tourism: An empirical investigation in a non-linear framework", International Journal of Tourism Research, Vol. 17 No. 3, pp. 272-281, available at: https://doi.org/10.1002/jtr.1985

Stock, M. and Lucas, L. (2012), "La double révolution urbaine du tourisme”, Espaces et Sociétés, Vol. 151 No. 3, p. 15, available at: https://doi.org/10.3917/esp.151.0015

Treisman, D. (2007), "What have we learned about the causes of corruption from ten years of CrossNational empirical research?”, Annual Review of Political Science, Vol. 10 No. 1, pp. 211-244, available at: https://doi.org/10.1146/annurev.polisci.10.081205.095418

Triantafyllopoulos, N. (2017), "On the origins of tourist urbanisation in Greece: Land speculation and property market (in)efficiency", Land Use Policy, Vol. 68, pp. 15-27, available at: https://doi.org/ 10.1016/j.landusepol.2017.06.007

Vallejo Pousada, R. (2013), “Turismo y desarrollo económico en España durante el franquismo, 19391975", Revista de la historia de la economía y de la empresa, Vol. 7, pp. 423-452, available at: https://dialnet.unirioja.es/servlet/articulo?codigo $=5831915$

Wall, G. and Mathieson, A. (2006), Tourism: Change, Impacts and Opportunities, Pearson Education, Harlow.

Yanes Torrado, S. (2017), "Malditas masas", Revista de la Taula Veïnal d’Urbanisme de Barcelona, Vol.1, pp. 9-14, available at: https://mareaurbanabcn.wordpress.com/2017/04/25/malditas-masas/

Corresponding author

Antonio-Miguel Nogués-Pedregal can be contacted at: amnogues@umh.es

For instructions on how to order reprints of this article, please visit our website:

www.emeraldgrouppublishing.com/licensing/reprints.htm

Or contact us for further details: permissions@emeraldinsight.com 